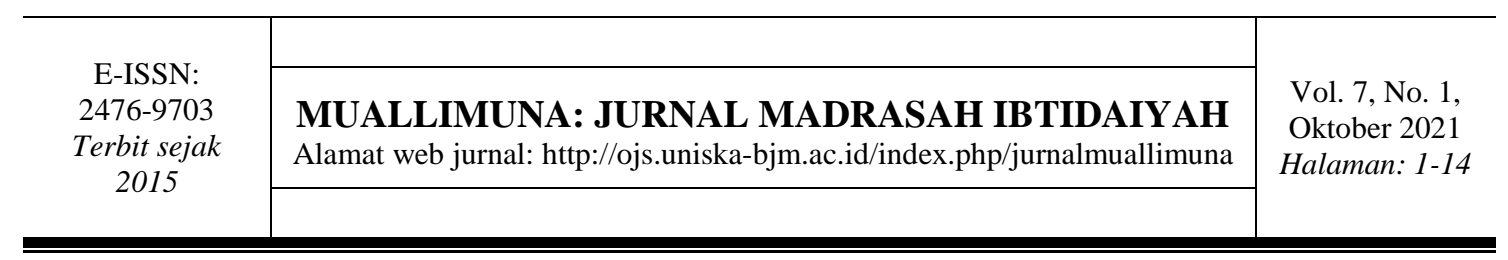

\title{
TANTANGAN GURU DALAM MENGAJAR DENGAN SISTEM WORK FROM HOME PADA MASA PANDEMI COVID-19 DI MADRASAH IBTIDAIYAH
}

\author{
$\operatorname{Hasan}^{1}$ \\ ${ }^{1}$ Pendidikan Guru Madrasah Ibtidaiyah, Institut Agama Islam Negeri Bone \\ 1hasan@iain-bone.ac.id
}

\begin{abstract}
Abstrak: Tujuan penelitian ini untuk mengetahui tantangan yang dihadapi guru dalam mengimplementasikan kompetensi pedagogik selama proses mengajar dengan sistem work from home. Penelitian ini berlokasi di sekolah Madrasah Ibtidaiyah Lemo Tua Desa Kuajang Kecamatan Binuang Kabupaten Polewali Mandar Provinsi Sulawesi Barat. Subjek penelitian adalah guru kelas sebanyak 6 orang. Penelitian ini merupakan studi kasus eksplorasi dengan menggunakan pendekatan penelitian kualitatif. Data dianalisis menggunakan teknik triangulasi. Hasil penelitian ditemukan bahwa tantangan yang dihadapi guru adalah 1) guru kesulitan dalam mencapai target pembelajaran sesuai dengan kurikulum 2) guru kesulitan dalam melaksanakan pembelajaran secara online menggunakan media teknologi 3) guru kesulitan dalam memberikan penilaian sesuai dengan instrumen validasi dan reliable data.Tantangan tersebut menyebabkan guru tidak dapat memaksimalkan kompetensi pedagogiknya dalam mengajar dengan sistem work from home. Peneliti menawarkan ide untuk menjawab tantangan tersebut yaitu, 1) perlu adanya penyederhanaan target pembelajaran dan penilaian, 2) perlu adanya pembekalan pengetahuan literasi digital dan penggunaan teknologi untuk guru, peserta didik dan orangtua, 3) perlu adanya pemberian subsidi smartphone bagi guru dan peserta didik selama pandemi.
\end{abstract}

\section{Kata Kunci: Tantangan Guru, Work From Home, Pandemi Covid-19}

\section{THE TEACHERS'CHALLENGES IN TEACHING THROUGH WORK FROM HOME SYSTEM IN THE COVID-19 PANDEMIC SITUATION AT MADRASAH IBTIDAIYAH}

\begin{abstract}
The purpose of this study wa to determine the challenge faced by teachers in implementin pedagogic competencies during the teaching process with a work from home system. This research is located at the Madrasah Ibtidaiyah Lemo Tua, Kuajang Village, Binuang District,Polewali Mandar Regency,West Sulawesi Province.The research subjects were 6 class teachers. This research is an exploratory case study using a qualitative research approach with data analysis techniques using triangulation. The results of the study found that the challenges faced by teachers were 1) teachers had difficulties in achieving learning targets according to the curriculum, 2) teachers had difficulties in implementing online learning using technology media, 3) teachershad difficulties in assessing student learning outcomes in accordance with validation instruments and reliable data. These challenges cause teachers to be unable to maximize their pedagogical competence in teaching with a work from home system. Researchers offer ideas to answer these challenges, namely,1) the need for simplification of learning
\end{abstract}


and assessment targets, 2) the need for provision of digital literacy knowledge and the use of technology for teachers, students and parents,3) the need for smartphone subsidies for teachers and students during the pandemic.

\section{Keywords: Teachers' Challenges, Work From Home, Covid-19 Pandemic}

\section{PENDAHULUAN}

Corona Virus Disease (COVID-19) telah membuat masyarakat berada dalam ketegangan dan ketakutan akan terjangkitnya virus yang mematikan ini termasuk negara Indonesia. Kasus COVID-19 di Indonesia diumumkan sejak 2 Maret 2020 (Kompas, 2020).Virus ini meluas dengan sangat cepat dari manusia ke manusia (Annisa,2020). Menyikapi penyebaran COVID-19 yang semakin meningkat, Pemerintah Indonesia mengeluarkan kebijakan melalui Surat Edaran Menteri Kesehatan No. HK.02.01/MENKES/199/2020 pada 15 Maret 2020 dan Surat Edaran Kemendikbu No. 36603/A.A5/OT/2020 tentang pencegahan.Berdasarkan surat tersebut,maka masyarakat dilarang berkumpul dan beraktivitas di luar rumah sehingga masyarakat diarahkan untuk beraktivitas dari rumah atau work from home (WFH) (Londa, 2020)

WFH dipilih sebagai pilihan utama dalam menekan laju perkembangan penyebaran COVID-19 dengan berdasar pada isi Undang-Undang Nomor 13 Tahun 2013 tentang hak keselamatan kerja (Pristiyono et al.,2020). Dampak dari kebijakan tersebut salah satunya berefek pada aspek pendidikan. Pandemi COVID-19 secara tibatiba mengharuskan pelaksanaan pengajaran dilakukan dengan cara online dengan menuntut guru dan dosen serta peserta didik agar dapat beradaptasi secara cepat dengan melakukan dan menerima inovasi pembelajaran berbasis online (Herliandry \& Suban, 2020). Keberhasilan penyelenggaraan pendidikan di masa pandemi dengan sistem WFH sangat ditentukan oleh kompetensi guru dalam mempersiapkan materi dan metode ajar yang akan diterapkan kepada peserta didiknya (Novitasari \& Asbari, 2020).

Mengajar dengan sistem work from home (WFH) di masa pendemi telah menjadi kajian menarik yang dibahas dalam beberapa penelitian sebelumnya. Tri, (2020) misalnya, secara khusus mendalami tentang pengaruh work from home (WFH) terhadap kinerja guru SD negeri Dengkek. Hasil penelitiannya menyimpulkan bahwa terdapat efek positif dan negatif pada program WFH. Dampak positifnya berupa kerja lebih tenang dan aman karena terhindar dari COVID-19, WFH juga secara signifikan mempengaruhi pengeluaran perjalanan menuju ke sekolah. Dampak negative dari WFH adalah WFH membuat guru dan peserta didik jenuh belajar di rumah. Selain itu, kajian tentang bekerja dengan sistem WFH juga dilakukan oleh (Purwanto, 2020) yang fokus pada kajian dampak kinerja guru sekolah dasar selama masa pendemi dengan sistem WFH.Hasil penelitiannya menunjukkan bahwa guru lebihfleksibel dalam menyelesaikan pekerjaan bagi yang memahami tentang teknologi, menurunnya biaya transportasi serta meminimalisir tingkat stress yang dialami guru akibat kemacetan di jalan menuju sekolah sedangkan dampak kerugian yang dialami guru berupa hilangnya motivasi kerja, biaya listrik dan kuota internet yang semakin meningkat serta tidak maksimalnya kerja dari rumah bagi yang tidak memahami penggunaan teknologi.

Penelitian tentang mengajar dengan sistem WFH juga dilakukan oleh (Ainur Risalah et al.,2020) dengan fokus kajian pada studi kegiatan belajar mengajar berbasis daring pada guru dan siswa. Hasil penelitiannya menyebutkan bahwa pembelajaran 
dengan sistem WFH sangat kurang efekif karena siswa sulit memahami materi ajar dan lebih banyak fokus untuk bermain games atau sosial media menggunakan hape.

Dari ketiga penelitian diatas yang telah dilaksanakan kecenderungan penelitian membahas tentang tantangan kinerja dalam perspekti kompetensi profesional guru yang bekerja dengan sistem WFH,dan belum membahas tentang bagaimana proses implementasi kompetensi pedagogik guru dalam pembelajaran online dengan sistem WFH selama pandemi ini. Berdasarkan hal tersebut, penelitian ini dimaksudkan untuk mengisi dan melengkapi ruang analisis tentang tantangan apa saja yang guru hadapi dalam mengajar melalui perspektif kompetensi pedagogik dengan sistem WFH. Penelitian ini selain "memetakkan permasalahan dan kendala yang dihadapi dan dijalani oleh para guru selama melaksanakan proses pengajaran, juga menganalisis tentang solusi dari permasalahan tersebut sehingga dapat menjawab tantangan yang dihadapi guru dan menjadi ide yang solutif.

Profesi guru merupakan profesi yang mempunyai kewajiban untuk mengetahui dan menguasai empat kompetensi sesuai dengan Undang-Undang Nomor 14 Tahun 2005.Kompetensi pedagogik adalah(Hendriana\&Jacobus, 2017) Kompetensi pedagogik merupakan kemampuan seorang guru untuk bisa mengelola pelaksanaan pembelajaran di kelas dengan membuat perancangan, pelaksanaan dan evaluasi hasil dan perkembangan peserta didik dalam pembelajaran. Pada era pandemi COVID-19 saat ini, guru menghadapi sebuah kondisi dan tantangan baru yang lebih kompleks dalam mewujudkan pembelajaran berkualiatas dengan tetap mengedepankan aspek kompetensi pedagogik Kompetensi pedagogik menjadi aspek yang harus diperhatikan oleh guru dalam proses pembelajaran. Guru harus dapat menciptakan proses pembelajaran yang menyenangkan dengan mengatur kondisi dan lingkungan untuk menstimulus siswa agar dapat melakukan interaksi dalam salah satu dari empat komptensi tersebut yang harus di kuasai. Menurut proses belajar (Jamilah, Mahutma Gandhi, 2020). Guru juga perlu mengubah mindset agar mampu berpikir secara logis, kritis, dan holistic terhadap kondisi saat ini (Astuti,2018) Mendidik, mengajar, membimbing, melatih, mengarahkan serta mengevaluasi siswa adalah tugas seorang guru. Guru menjadi faktor yang sangat dominan dalam pendidikan karena guru dijadikan contoh yang baik bagi siswa (Hasan, 2019).

Tantangan pendidikan saat ini memaksa para guru dan peserta didik agar mampu survive menghadapi kondisi sebagai bagian dari perjalanan pendidikan dalam mencerdaskan kehidupan bangsa dan negara (Ranti,2018). Kompetensi pedagogik tersebut harus dapat dilaksanakan secara tuntas walaupun proses pembelajaran dilakukan secara online. Tidak hanya itu,penerapan kompetensi pedagogik juga harus bisa dioptimalkan dengan baik agar proses pengajaran menjadi lebih berkualitas (Nengsih, 2017).

Undang-Undang Nomor 14 Tahun 2005 mengatakan bahwa guru bertugas untuk "mengajar, mendidik, membimbing, melatih, mengarahkan serta mengevaluasi siswa dalam pendidikan formal mulai jenjang usia sekolah dini, sekolah dasar, serta menengah merupakan tugas seorang guru. Uraian tugas tersebut menjelaskan bahwa guru merupakan jabatan profesional yang mempunyai latar belakang pendidikan pada bidang keguruan untuk mendidik. Sehingga,tidak mengherankan jika pendidikan dijadikan sebagai instrumen untuk memanusiakan manusia yang dilakukan oleh para guru (Hasan, 2018). Selain itu, kemahiran dan keterampilan kompetensi pedagogik seorang guru juga sangat perlu dimiliki agar dalam menjalankan tugas dapat dilaksanakannya dengan baik (Suasthi et al., 2020). Penyelenggaraan pelaksanaan pembelajaran 
online dengan sistem WFH dapat berjalan dan terlaksana dengan baik, jika guru memiliki kompetensi yang baik pula (Kahfi, 2020) serta memiliki karakter dan mental yang kuat dalam melaksanakan proses mengajar (Lubis \& Nasution, 2017).

Pelaksanaan pembelajaran online dengan sistem WFH dijadikan sebagai ruang kelas baru untuk interaksi antara siswa dan guru (Purwanto,2020). Efektifitas pembelajaran online dapat terlaksana secara efektif jika dilengkapi media ajar yang tepat untuk mendorong ketercapaian pelaksanaan pembelajaran $(\mathrm{H}$. H. Batubara \& Batubara, 2020). Sejalan dengan hal tersebut Diani\&Dewi,(2020) mengatakan bahwa pembelajaran online memiliki manfaat dan kemudahan diantaranya jadwal lebih fleksibel, ketersediaan media dan konten yang beragam serta pembelajaran dapat diakses secara cepat dari rumah. Namun, kenyataannya perwujudan tersebut hanya terjadi bagi guru dan peserta didik yang tinggal di perkotaan dengan akses internet yang memadai serta memilik pengetahuan dan kemampuan finansial yang cukup.

Pembelajaran online dengan sistem WFH bukanlah sesuatu yang mudah dilaksanakan apalagi jika sekolah tersebut berada pada lokasi pedesaan yang akses signal internetnya kurang stabil.Selain itu, kualitas pengetahuan sumber daya manusia yang kurang juga akan mempengaruhi kualitas pelaksanaan pembelajaran dengan sistem online. Tentunya hal ini akan menjadi kendala dan tantangan besar bagi seluruh pihak yang akan melaksanakan proses pembelajaran seperti guru, peserta didik dan orang tua. Ketidakstabilan signal internet, keterbatasaan akses teknologi terutama smartphone, kurangnya pengetahuan pendampingan orang tua di rumah terhadap anaknya dalam belajar serta kurang kompotennya guru dalam melakukan pembelajaran online akan mewarnai proses pembelajaran dengan sistem work from home di masa pandemi ini. Kondisi ini menjadi kekhawatiran bagi semua pihak di lembaga pendidikan bahwa guru dan peserta didik akan mengalami penurunan kualitas akademik dan kreatifitas. Hal tersebut sesuai degan pernyataan D. S. Batubara, (2015) bahwa Stimulus yang kurang baik maka dapat mematikan kreatifitas anak.

Kajian lebih lanjut dalam penelitian adalah peneliti melakukan penelitian di sebuah sekolah yang menerapkan sistem work from home namun memiliki akses internet yang kurang memadai serta kurangnya kemampuan penggunan teknlogi bagi guru dan peserta didiknya tepatnya di Madrasah Ibtidaiyah (MI) Lemo Tua Desa Kuajang Kecamatan Binuang Kabupaten Polewali Mandar Provinsi Sulawesi Barat. Penelitian ini dilaksanakan berdasarkan pada kasus yang telah disebutkan sebelumnya guna mengetahui tantangan yang dihadapi guru dalam mengimplementasi kompetensi pedagogik selama proses mengajar dengan sistem work from home ditinjau dari cara guru mencapai target pembelajaran, pemilihan media ajar, serta penilaian.

\section{METODE}

Penelitian ini menggunakan metode studi kasus eksplorasi dengan pendekatan penelitian kualitatif. Menurut Creswell studi kasus kualitatif dilakukan apabila peneliti ingin memahami secara mendalam suatu permasalahan dengan cara mengidentifikasi kasus yang kaya informasi dari suatu fenomena (Kusmarni, 2015) dan obyek yang diteliti apa adanya sesuai dengan kondisi yang ada (Barsihanor,Liani,2021). Wahidmurni, (2017) mengatakan bahwa penelitian kualitatif bersifat deskriptif dengan menggunakan analisis pendekatan induktif. Penelitian yang menggunakan metode deskriptif juga berusaha menemukan fakta dengan interpretasi yang tepat dalam sebuah fenomena di lapangan (Dewi \& Hidayah, 2019). Pelaksanaan penelitian berlangsung sejak tanggal 5 Februari- 20 Februari 2021. 
Data utama pada penelitian ini bersumber dari data primer dan data sekunder. Data primer dikumpulkan menggunakan teknik wawancara semi-terstrutur dan data sekunder dikumpulkan dari data publikasi diantaranya artikel jurnal dan buku. Data wawancara yang dikumpulkan berupa ungkapan,persepsi/pendapat para informan tentang tantangan yang dihadapi dalam proses mengajar.

Wawancara semi terstruktur menurut Suwartono, n.d (2007) merupakan teknik wawancara yang menempatkan pewawancara sebagai pengarah pembicaraan.Lebih lanjut Rachmawati, (2007) juga mengutarakan bahwa wawancara semi terstruktur adalah wawancara yang memiliki pedoman fokus pada area tertentu namun dapat direvisi disaat proses interview ketika peneliti menemukan sebuah ide untuk dikembangkan melalui pertanyaan. Dalam teknik ini, peneliti mengembangkan pertanyaan dari topik atau isu yang ada atau sedang berkembang secara lengkap untuk mendapatkan data kualittif yang lebih mendalam.

Subjek yang menjadi informan dalam memberikan informasi adalah guru kelas di Madrasah Ibtidaiyah Lemo Tua sebanyak 6 orang dengan rincian profil sebagai berikut:

Tabel I. Profil Responden

\begin{tabular}{ccccc} 
Inisial & Jenis Kelamin & Kelas & Pendidikan & Usia \\
\hline I1 & Perempuan & 1 & S1 & 38 \\
\hline I2 & Laki-Laki & 2 & S1 & 47 \\
\hline I3 & Perempuan & 3 & S1 & 37 \\
\hline I4 & Perempuan & 4 & S1 & 31 \\
\hline I5 & Perempuan & 5 & S1 & 48 \\
\hline I6 & Laki-Laki & 6 & S1 & 46
\end{tabular}

Peneliti menggunakan teknik purposive sampling dalam menentukan sample. Teknik pusrposive sampling pada penelitian kualitatif berfungsi sebagai metode yang digunakan oleh peneliti untuk mencapai tujuan penelitian yang telah ditetapkan dan tidak terdapat batasan jumlah informan untuk membuat sample pusposive asalkan informasi yang diinginkan dapat diwujudkan (Mujahidin, 2019). Creswell (2013) memberikan beberapa pengamatan ukuran sample untuk penelitian studi kasus berkisar tidak lebih dari 4-5 kasus.

Sejalan dengan metode yang digunakan, penelitian ini melalui tiga prosedur proses atau tahapan yaitu pertama tahan pra-riset riset dan analisis data. Pada tahapan pertama peneliti mengumpulkan temuan data awal berupa permasalahan yang terjadi salama proses pembelajaran dengan sistem WFH melalui observasi langsng ke lapangan kemudian menyusun rencana penelitian.Tahapan ke dua yaitu tahap riset, peneliti mengambil data dengan dua cara yaitu wawancara dan pengambilan dokumentasi secara langsung ke sekolah. Pada tahapan ke tiga, peneliti menganalisis data yang telah di peroleh

Pengambilan dan anailisis data dilaksanakan secara bersamaan atau terpadu. Artinya, peneliti telah menganalisis data saat penelitian dilaksanakan di lapangan sesuai dengan data empiris yang didapatkan.Data empiris yang telah diperoleh kemudian dianalisis melalui tiga langkah analisis sesuai dengan yang disarankan oleh Iles dan Huberman dalam denzim dan Lincoln, 1994 yaitu menggunakan triangulasi data yaitu reduksi data, pemaparan dan verifikasi atau penarikan kesimpulan untuk menjawab pertanyaan peneliti tentang tantangan yang dihadapi guru dalam mengimplementasi kompetensi pedagogik selama proses mengajar dengan sistem work from home ditinjau dari cara guru mencapai target pembelajaran, pemilihan media ajar, serta penilaian. 


\section{HASIL DAN PEMBAHASAN \\ Hasil}

COVID-19 telah berhasil menggiring proses belajar mengajar dari tatap muka secara langsung beralih ke kelas pertemuan secara online yang dilaksanakan dari rumah tentang tantangan yang dihadapi guru saat mengimplementasi kompetensi pedagogik selama proses mengajar dengan sistem work from home (WFH) ditinjau dari cara guru mencapai target pembelajaran, pemilihan media ajar, serta penilaian di sekolah Madrasah Ibtidaiyah Lemo Tua Desa Kuajang Kecamatan Binuang Kabupaten Polewali Mandar menjadi tujuan pada penelitian ini. Data diperoleh dengan cara wawancara semi terstruktur kepada 6 informan guru kelas. Semua hasil tanggapan dari informan adalah kutipan asli. Pernyataan mereka kemudian diuraikan dalam bentuk narasi sesuai dengan informasi yang disampaikan oleh informan.

Beikut hasil pernyataan yang disampaikan oleh para informan yang telah di narasikan:

I.1: Informan berjenis kelamin perempuan yang merupakan guru kelas 1 menyatakan bahwa:

Selama dikeluarkannya edaran untuk melaksanakan kegiatan mengajar dengan sistem work from home, maka bersama itu pula, saya selaku guru kelas 1 mengalami kebingungan dalam proses pembelajaran. Kebinguungan tersebut karena siswa yang berada pada kelas 1 adalah siswa yang masih perlu dibimbing secara tatap muka langsung dan belum mengerti dengan istilah belajar dari rumah. Selain itu,siswa kelas 1 juga belum mengerti menggunakan handphone untuk mengikuti proses pembelajaran sehingga saya masih sulit untuk menerapkan pembelajaran secara online Saya juga tidak bisa menggunakan aplikasi dalam proses pembelajaran, selain karena siswa yang tidak mengerti penggunaan media juga karena tidak semua siswa memiliki handphone untuk mengikuti pembelajaran secara online.Jadi untuk memberika nilai hasil belajar kepada siswa tidak dapat dilakukan sesuai dengan target capaian kurikulum karena akan banyak siswa yang akan mendapatkan nilai rendah. Jadi pola yang saya terapkan untuk proses pembelajaran selama ini adalah menelfon orang tua siswa untuk mengambil materi ajar sebanyak 2 kali seminggu secara bergantian di rumah saya. Untuk pengumpulan tugas, saya meminta kepada orangtua siswa untuk mengantarkan anaknya ke rumah saya sesuai dengan jadwal yang telah saya berikan. Untuk sistem penilaian saya terapkan penilaian langsung hasil kerja agar dapat mengetahui perkembangan peserta didik.

1.2: Informan berjenis kelamin Laki-Laki yang merupakan guru kelas 2, informasi yang berhasil didapatkan sebagai berikut:

Saya sebagai guru kelas 2 merasakan syok ketika diperintahkan untuk melaksanakan proses mengajar dengan sistem work from home.Saya pribadi belum pernah melaksanakan proses mengajar tanpa tatap muka secara langsung dengan siswa. Saya juga merasakan adanya kendala dalam proses mengajar secara online karena tidak semua siswa kelas 2 memiliki handphone android serta tidak stabilnya akses internet di desa ini sehingga meteri yang diberikan tidak semua tersampaikan dengan baik kepada peserta didik seperti pada kegiatan mengajar tatap muka di kelas. Saya juga merasa kesulitan untuk menilai hasil pembelajaran siswa secara keseluruhan karena proses interaksi antara saya dengan peserta didik tidak berjalan dengan baik secara online dikarenakan saya secara pribadi tidak menguasai penggunaan teknologi dalam mengajar. Jadi selama proses mengajar 
saya hanya menggunakan media WhatsApp dalam berkomuniaksi dengan peserta didik itupun tidak semua peserta didik memiliki handphone android sehingga masih terdapat siswa yang tertinggal ketika belajar. Jadi untuk mencapai hasil belajar siswa sesuai dengan target capaian kurikulum sangat sulit untuk dicapai.

1.3: Informan berjenis kelamin perempuan yang merupakan guru kelas 3, pernyataan yang diberikan adalah:

Saat saya memberitahukan kepada siswa kelas tiga yang saya ajar sebanyak 18 orang bahwa proses pembelajaran akan dilaksanakan secara online dari rumah, maka seketika itu pula siswa memperlihatkan wajah kebingungan dan berupaya untuk protes. Jadi tantangan saya diawal adalah berusaha meyakinkan kepada siswa bahwa proses pembelajaran akan berjalan seperti biasanya, dan yang membedakan hanya tempat atau ruangan kelasnya saja Namun karena siswa kelas 3 ini adalah siswa yang sudah memiliki rasa keinginantahuannya tinggi sehingga banyak hal yang mereka tanyakan. Saya juga agak kewalahan dalam mencapai target pembelajaran yang telah ditetapkan karena proses mengajar saya dengan peserta didik hanyamelalui media WhatsApp.Jadi saya mengajar dan menyampaikan materi melalui chat WA dan ini saya rasakan tidak maksimal. Ketika saya ingin menggunakan media lain seperti zoom dll, saya selalu was-was karena tidak bisa mengoperasikannya meskipun sudah di ajari.Untuk penilaian hasil kerja siswa saya terapkan penilaian langsung dengan cara voice note antara saya dan siswa.

1.4: Informan berjenis kelamin perempuan yang merupakan guru kelas 4, pernyataan yang diberikan adalah:

Awalnya ketika semua guru diminta untuk melanjutkan proses mengajar dari rumah atau work from home secara online membuat saya gemetaran dan ketakutan serta, merasa kurang senang dan kurang nyaman dengan arahan ini. Hal yang membuat saya tidak nyaman adalah saya termasuk generasi yang terlambat mengenal dunia teknologi sehingga untuk melakukan proses pembelajaran menggunakan IT secara online membuat saya tidak percaya diri dan takut. Sehariharinya saya berkomunikasi hanya menggunakan handhone "kitu-kitu" Bahasa orang di kampung ini yaitu hape yang hanya bisa digunakan menelfon dan sms, saya tidak tahu menggunakan handphone android apalagi mengoperasikan laptop. Jadi pola yang saya lakukan agar proses mengajar tetap berjalan adalah mendatangi siswa secara bergantian yang berjumlah 20 orang untuk memberikan materi. Meskipun pola ini sangat sulit namun bagi saya tidak ada pilihan lain,dan inilah efek akibat gaptek. Pola ini saya rasakan sulit untuk mencapai target penilaian pembelajaran yang efektif. Untuk sistem penilaian, sebelum ada pandemi saya terapkan 2 kali penilaian di awal dan di akhir pertemuan secara keseluruhan, namun untuk saat ini saya menerapkan penilaian perindividu secara langsung setelah proses pembelajaran selesai dan hal ini cukup menyita waktu.

1.5: Informan berjenis kelamin perempuan yang merupakan guru kelas 5 , pernyataan yang diberikan adalah:

Saya sebagai guru kelas lima di sekolah ini sudah mengabdi selama 15 tahun. Namun baru kali ada bencana yang berhasil menutup sekolah untuk tidak melakukan proses pembelajaran sampai waktu yang tidak ditentukan. Proses pembelajarannyapun harus dilaksanakan secara online menggunakan aplikasi dan dilaksanakan dari rumah. Saya secara pribadi sangat khawatir dengan kondisi 
peserta didik yang diajar tanpa ketemu langsung di kelas. Bagi saya mengajari siswa tanpa tatap muka langsung akan mengurangi kedekatan secara emosional dengan siswa sehingga akan menyebabkan siswa merasa malu-malu dengan gurunya.Selama proses mengajar ini, saya hanya menggunakan aplikasi WhatsApp untuk mengecek kehadiran siswa, mengecek tugas siswa, menilai dan mengajar.Saya memilih menggunakan WhatsApp karena lebih mudah digunakan. Saya juga pernah mendengar aplikasi zoom, classroom namun guru seperti saya sudah sulit untuk menggunakanya karena tidak terbiasa.Penilaian yang saya terapkan tidak mengikuti standar penilaian capaian pembelajaran yang telah ditetapkan.

1.6: Informan berjenis kelamin perempuan yang merupakan guru kelas 6, pernyataan yang diberikan adalah:

Pada saat saya mendengarkan informasi dari Kepala Sekolah bahwa akan dilaksanakan proses pembelajaran dari rumah atau mengajar dari rumah work from home. Saya pribadi menyambut baik kesempatan ini untuk memperkenalkan media pembelajaran IT kepada siswa dan pihak sekolah. Saya berpikir sudah waktunya belajar dengan IT, namun tantangannya adalah fasilitas internet yang belum memadai dan smartphone android yang belum dimiliki oleh semua siswa sehingga masih sulit untuk menerapkan pembelajaran online secara total. Jadi pola yang saya terapkan agar dapat mengajar dengan sistem work from home secara online adalah saya membuat 2 kelompok belajar yaitu 1 kelompok belajar yang bisa menggunakan smartphone android secara daring dan lkelompok belajar yang secara luring dengan cara belajar secara bergantian di rumah saya dengan tetap mematuhi protokok kesehatan. Namun untuk mencapai target hasil belajar masih sangat sulit karena siswa sulit untuk focus belajar begitupun dengan saya ketika sudah mengalami kelelahan. Hal ini membuat saya harus menyiapkan waktu dan tenaga lebih agar semua siswa dapat belajar. Untuk proses penilaian, Saya menilai siswa secara langsung di akhir pembelajaran meskipun ada yang siap di nilai dan tidak.

\section{Pembahasan}

Proses mengajar yang dilaksanakan dengan cara online memiliki perbedaan yang sangat signifikan dengan proses mengajar secara langsung di kelas dalam mengimplementasikan kompetensi pedagogik. Hal ini tergambarkan pada saat peneliti melakukan wawancara kepada para informan. Dari hasil wawancara menunjukkan bahwa masi terdapat beberapa kendala yang guru alami sehingga guru kesulitan mengimplementasikan secara maksimal kompetensi pedagogik pada pembelajaran daring dengan sistem WFH dalam mencapai target pembelajaran. Kendala tersebut sangat mempengaruhi hasil kualitas kompetensi pedagogik guru dalam melakukan transfer pengetahuan kepada para peserta didik. Kompetensi pedagogik guru erat kaitannya dengan tugas perencanaan, pengelolaan atau pelaksanaa serta penilaian atau evaluasi hasil belajar peserta didik (Ismail, 2010).

Kompetensi yang baik akan membuat guru mampu merancang, melaksanakan dan mengevaluasi proses pembelajaran serta memberikan hasil pemahaman yang baik pula bagi peserta didik (Jamilah, Mahutma Gandhi, 2015). Guru memiliki tanggungjawab dalam membimbing dan mengarahkan peserta didik sampai batas kemampuan maksimal (Seknun, 2012). 
Berdasarkan data yang didapatkan menyatakan bahwa secara keseluruhan guru kelas kesulitan untuk mencapai target pembelajaran kurikulum yang telah ditetapkan oleh pemerintah atau lembaga pendidikan dengan sistem pembelajaran WFH. Kondisi pandemi membatasi ruang gerak guru untuk mewujudkan capaian tersebut karena jika dipaksakan maka resiko terpapar virus corona akan meningkat, namun jika proses pembelajaran dilaksanakan tanpa adanya capaian target maka guru tidak akan memiliki ukuran ketercapaian pembelajaran.

Selain capain target pembelajaran yang sulit dipenuhi oleh guru, tantangan guru selanjutnya adalah bagaimana guru mampu memilih dan menggunakan media dalam menstransfer materi ajar dengan baik. Guru diharapkan tidak hanya dapat mengimplementasikan kompetensi pedagogiknya dalam pembelajaran offline saja tetapi juga pada pembelajaran online. Di era pandemi COVID-19, kompetensi pedagogik guru diuji secara professional. Guru harus mampu menanamkan nilai-nilai pendidikan dalam proses pembelajaran secara edukatif dan mudah dimengerti oleh peserta didik seperti saat pembelajaran langsung di kelas menggunakan media. Kondisi ini menuntut guru untuk bisa menggunakan teknologi pembelajaran maupun media belajar lainnnya diantaranya zoom, google meet, classroom dsb. Penggunaan media online dalam pembelajaran terbukti menjadi tantangan baru bagi guru di masa pandemi ini.Terdapat 4 guru kelas tidak dapat menunjukkan kompetensi pedagogiknya dalam proses mengajar menggunakan media online seperti zoom, google meet, classroom karena tidak menguasai teknologi serta jaringan internet yang tidak stabil sehingga para guru menggunakan aplikasi WhatsApp sebagai media pembelajaran untuk berkomunikasi kepada para peserta didik.

Dalam kondisi darurat ini, pembelajaran sekolah sebagian besar dilakukan secara online sehingga mempengaruhi proses penilaian yang dilaksanakan secara online pula. Proses penilaian ini tentunya memiliki perbedaan, sehingga hasil penilaian yang didapatkan bukan menjadi rujukan penilaian standar pad umumnya. Penilaian ini untuk membantu mendapatkan informasi tentang kemajuan peserta didik serta dijadikan sebagai acuan untuk perkembangan peserta didik.

Data yang tela diperoleh sesuai dengan hasil penelitian menunjukkan bahwa 6 guru kelas mengatakan penilaian yang mereka lakukan sebelum adanya COVID-19 adalah penilaian yang menggabungkan antara format penilain sumatif dan format penilaian formatif secara bersamaan. Namun saat pandemi ini, penilaian dengan format sumatif sulit mengukur tingkatvaliditas kerja siswa karena ada kecenderungan hasil belajar siswa mendapatkan bantuan dari keluarga atau menyontek. Guru melakukan penilaian dengan format formatif dengan tujuan mengarahkan sisw mengetahui pola dan konsep materi secara baik, tepat dan benar. Para guru umumnya melakukan penilaian dengan 2 cara yaitu pertama penilaian siswa melalui smartphone bagi yang memilikinya. kedua penilaian dilakukan dengan berkunjung langsung kerumah siswa bagi yang tidak memiliki smartphone.

Tantangan pembelajaran yang dihadapi guru di masa ini sangat mempengaruhi pada kualitas aspek pedagogik guru. Aspek tersebut mencakup aspek perencanaan, aspek pelaksanaan pembelajaran dan aspek penilaian/evaluasi pembelajaran. (Sodik et al., 2019). Untuk mengetahui lebih lanjut, maka penulis menguraikan kompetensi guru dalam mengajar pada aspek pedagogik sebagai berikut :

1. Aspek Pedagogik guru pada Perencanaan Pembelajaran

Guru sebagai pendidik profesional bertugas untuk memberikan pembelajaran kepada peserta didik.Berbagai persiapan dilakukan oleh guru sebelum melakukan pembelajaran online meskipun dilaksanakan secara WFH, salah satunya adalah membuat rencana pembelajaran.Berdasarkan hasil penelitian yang didapatkan 
bahwa para guru tidak mengalami kendala berarti dalam membuat rencana pembelajaran. Umumnya, rencana pembelajaran yang dibuat oleh guru seperti memformulasikan tujuan pembelajaran kedalam RPP sesuai dengan karakteristik kondisi siswa, membuat bahan ajar secara mutakhir dan konstektual serta logis, menyusun pembelajaran yang efektif, serta mengembangkan sumber belajar atau media pembelajaran sesuai dengan isi materi.Jadi pada aspek kinerja perencanaan pembelajaran guru tidak mengalami kendala atau hambatan yang berat.

2. Aspek Pedagogik Guru pada Pelaksanaan Pembelajaran

Guru telah membuat rencana pembelajaran yang efektif dan efisien.Tujuannya agar proses mengajar dapat berjalan dengan baik dilapangan, namun nyatanya berbanding terbalik dengan apa yang telah dilaksanakan. Guru sulit memformulasikan tujuan pembelajaran kedalam RPP sesuai dengan karakteristik siswa karena kurangnya interaksi peserta didik dan guru. Guru sulit membuat bahan ajar secara mutakhir dan konstektual serta logis karena ketidakmampuan dan ketidaksiapan peserta didik melakukan proses pembelajaranonline menggunakan smartphone.Guru sulit menyusun pembelajaran yangefektif karena kurangnya komunikasi dan interaksi, serta ketidakpahaman beberapa orang tua peserat didik dalam mendampingi anaknya selama proses belajar. Selain itu, Guru juga sulit mengembangkan sumberbelajar atau media pembelajaran sesuai dengan isi materi karena masih ada sebagian peserta didik dan orang tua yang tidak memiliki smartphone sehingga informasi tidak tersampaikan secara bersamaanJadi penerapan aspek pedagogik pada pelaksanaan pembelajaran guru mengalami tantanga yang berarti.

3. Aspek Pedagogik Guru pada Penilaian/Evaluasi Pembelajaran

Penilaian dalam proses pembelajaran mutlak dilakukan agar dapat mengetahui tingkat pencapaian dari target yang telah ditetapkan.Berbagai instrumen penilaian telah dipersiapkan guru sebelum melakukan proses pembelajaran. Penilaian bisa dilaksanakan setiap pertemuan, setiap bulan dan setiap semester sesuai dengan tingkat kebutuhan seorang guru dalam mengevaluasi siswanya. Namun dalam kondisi saat ini, berdasarkan data yang diterima para guru tidak dapat melaksanakan penilaian secara bersamaan. Penyebabnya karena proses pelaksanaan pembelajaran yang tidak berjalan dengan baik dan efektif, penilaian tidak dilakukan secara maksimal. Para guru umumnya melakukan penilaian dengan 2 cara yaitu pertama penilaian siswa melalui smartphone bagi yang memilikinya. kedua penilaian dilakukan dengan berkunjung langsung kerumah siswa bagi yang tidak memiliki smartphone. Jarak yang begitu jauh dari rumah ke rumah membuat sitem penilaian harus dilaksanakan dalam beberapa hari. Hal ini membuat adanya keterlambatan dalam melakukan proses penilaian. Jadi pada aspek pedagogik penilaian/evaluasi, guru mengalami tantangan dalam mewujudkannya.

Sebagai bentuk kepedulian dan usaha peneliti untuk menjawab tantangan tersebut, peneliti menawarkan beberapa ide yang bisa direalisasikan melalui kerja sama dengan lembaga terkait dan pemerintah secara langsung.

1. Target pembelajaran sebuah pendidikan merupakan pedoman yang sudah di rancang oleh pemerintah Target tersebut sebagai pedoman pelaksana dalam mengukur tingkat pencapaian dalam pelaksanaan pembelajaran yang telah dilaksanakan. Namun untuk masa pendemi ini, pemerintah perlu melakukan revisi ketercapaian pembelajaran dalam kurikulum dengan cara melakukan 
penyederhanaan capaain target untuk memudahkan para guru dalam membuat materi ajar yang sesuai dengan kondisi pandemic saat ini. Selain memudahkan para guru, juga akan memudahkan para siswa dalam menerima materi ajar karena telah disesuaikan situasi dan kondisi belajar dengan sistem WFH.

2. COVID-19 telah memberikan pelajaran berarti bagi dunia pendidikan khususnya dalam proses pembelajaran. Ketidaksiapan pemangku kepentingan danpelaksana pendidikanmenyambut erra digital menjadi kendala besar dalam proses belajar mengajar saat ini. Pembekalan pengetahuan literasi digital dan penggunaan teknologi untuk guru, peserta didik dan orangtua menjadi pilihan yang harus dilakukan.Solusi ini menjadi pilihan utama dalam menyelamatkan proses pembelajaran agar tetap berjalan dengan baik.Adanya pandemi COVID-19 harusnya bisa membuka mata kita semua bahwa ternyata pemerataan kualitas para pendidik di Indonesia belum merata secara baik khusnya bagi para pendidik yang berada di pedesaan. Mereka masih gaptek dan belum melek teknologi, termasuk peserta didik dan orangtua. Hal ini terbukti dengan sulitnya mereka menjalankan pembelajaran dengan sistem work from home menggunakan berbagai aplikasi.Untuk itu perlu adanya pembekalan penggunaan teknologi secara bertahap dan menyeluruh diberikan untuk guru, peserta didik maupun orangtua. Selain pembekalan penggunaan teknologi, pembekalan pengetahuan literasi digital juga harus diperkuat, sebagai upaya agar guru dan peserta didik dapat bijak dalam menggunakan smartphone dan internet.

3. Memberikan subsidi smartphone bagi guru dan peserta didik selama pandemi. Ide ini menjadi pertimbangan pemerintah sebagai upaya memenuhi kebutuhan proses belajar dan mengajar dengan sistem work from home bagi guru dan peserta didik selama pandemi.Rendahnya perekonomian masyarakat di daerah-daerah terpencil, termasuk di daerah tempat penelitian ini dilakukan, membuat guru dan peserta didik kesulitan membeli dan memiliki smartphone untuk proses pembelajaran selama pandemi. Dengan adanya subsidi smartphone yang diberikan pemerintah, akan membantu meringankan beban mereka dalam memiliki smartphone, sehingga proses pembelajaran dengan sistem work from home mudah dilakukan.

\section{PENUTUP}

Guru yang mengajar selama masa pandemi dengan sistem work from home mengalami beberapa kendala yang menjadi tantangan diantaranya :1) guru kesulitan dalam mencapai target pembelajaran sesuai dengan kurikulum 2) guru kesulitan dalam melaksanakan pembelajaran secara online menggunakan media teknologi 3) guru kesulitan dalam memberikan penilaian sesuai dengan instrumen validasi dan reliable data. Tantangan tersebut menyebabkan guru tidak dapat memaksimalkan kompetensi pedagogiknya dalam mengajar dengan sistem work from home. Peneliti menawarkan ide untuk menjawab tantangan tersebut yaitu, 1) Perlu adanya penyederhanaan target pembelajaran dan penilaian, 2) perlu adanya pembekalan pengetahuan literasi digital dan penggunaan teknologi untuk guru, peserta didik dan orangtua, 3) perlu adanya pemberian subsidi smartphone bagi guru dan peserta didik selama pandemi. Kompetensi pedagogik guru pada aspek perencanaan menunjukkan bahwa guru tidak mengalami kendala berat dalam melaksanakannya. Kompetensi 
pedagogik guru pada aspek pelaksanaan pembelajaran menunjukkan guru mengalami kendala dan tantangan yang berat dalam melaksanakannya. Kompetensi pedagogik guru pada aspek penilaian menunjukkan guru mengalami kendala karena harus dilaksanakan dengan 2 cara yaitu dengan 1) menggunakan smartphone dan 2) mengunjungi rumah siswa satu persatu untuk melakukan evaluasi.

\section{UCAPAN TERIMA KASIH}

Penulis awali ucapan terima kasih ini dengan bersyukur kepada Allah SWT yang telah memberikan kesehatan dan kemudahan kepada penulis dalam melakukan penelitian. Ucapan terima kasih selanjutnya saya kepada Kepala Sekolah, Guru dan Tenaga Kependidikan sekolah Madrasah Ibtidaiyah Lemo Tua beserta seluruh steakholder yang telah memberikan bantuannya berupa data dan informasi. Selanjutnya saya juga mengucapkan terima kasih kepada istri dan anak saya yang sudah memahami dan mensupport dalam melakukan penelitian ini serta kedua orang tua dan adik yang tak henti-hentinya memanjatkan doa bagi penulis. Terakhirsaya juga mengucapkan terima kasih kepada Institusi tempat saya mengabdi yaitu Program Studi Pendidikan Guru Madrasah Ibtidaiyah Fakultas Tarbiyah Institut Agama Islam Negeri Bone Sulawesi Selatan yang telah mendukung sepenuhnya dalam penulisan artikel ini.

\section{DAFTAR PUSTAKA}

Ainur Risalah, W Ibad, L Maghfiroh, M I Azza, S A Cahyani, \& Z A Ulfayati. (2020). Dampak Pandemi Covid-19 Terhadap Kegiatan Belajar Mengajar Di MI/SD (Studi KBM Berbasis Daring Bagi Guru dan Siswa). JIEES : Journal of Islamic Education at Elementary School, 1(1), 10-16. https://doi.org/10.47400/jiees.v1i1.5

Annisa, A. (2020). TANTANGAN GURU DALAM PROSES PEMBELAJARAN DARING DI MASA PANDEMI COVID-19. Journal of Chemical Information and Modeling, 53(9), 1689-1699.

Astuti, E. T. (2018). Pengembangan Permainan Tradisional Boi-Boian Dalam Menanamkan Pola Pikir Sains Anak Sekolah Dasar. Muallimuna: Jurnal Madrasah Ibtidaiyah, 4(1), 24. https://doi.org/10.31602/muallimuna.v4i1.1272

Barsihanor, Liani, S. (2021). Peran Guru Pendamping Khusus pada Program Layanan Pendidikan Inklusi di TK Idaman Banjarbaru. Indonesian Journal of Early Childhood: Jurnal Dunia Anak Usia Dini, 3(1), 7-15. https://doi.org/10.35473/ijec.v3i1.828

Batubara, D. S. (2015). Studi Kasus Tentang Kreativitas Guru Pada Pembelajaran Tematik Integratif di SD Anak Saleh Malang. Muallimuna: Jurnal Madrasah Ibtidaiyah, 3(2), 116-127.

Batubara, H. H., \& Batubara, D. S. (2020). Penggunaan Video Tutorial Untuk Mendukung Pembelajaran Daring Di Masa Pandemi Virus Corona. Muallimuna: Jurnal Madrasah Ibtidaiyah, 5(2), 21. https://doi.org/10.31602/muallimuna.v5i2.2950

Dewi, R. P., \& Hidayah, S. N. (2019). Metode Study Kasus. Syariah Stain Sorong, 19.

Diani, W. R., \& Dewi, L. S. (2020). Tantangan Guru BIPA Menghadapi Pembelajaran Daring. Transformatika, 4(2), 1-15. https://doi.org/10.31002/transformatika.v 
Hasan, H. (2018). KAMPUNG PENDIDIKAN DALAM PEMBERDAYAAN PARTISIPASIMASYARAKAT DESA YANG BERKARAKTER DAN BERDAYA SAING. Jurnal Terapan Abdimas, 3(2), 135-146. https://doi.org/10.25273/jta.v3i2.2803

Hasan, H. (2019). Penerapan Metode Permainan Aktif Menggunakan Media Daur Ulang Sampah Untuk Meningkatkan Karakter Peduli Lingkungan Pada Anak Di Paud Permata Hati. Jurnal Tumbuh Kembang: Kajian Teori Dan Pembelajaran PAUD, 6(2), 163-170. https://ejournal.unsri.ac.id/index.php/tumbuhkembang/index

Hendriana, E. C., \& Jacobus, A. (2017). IMPLEMENTASI PENDIDIKAN KARAKTER DI SEKOLAH MELALUI KETELADANAN DAN PEMBIASAAN. JPDI (Jurnal Pendidikan Dasar Indonesia), 1(2), 25-29. https://doi.org/10.26737/jpdi.v1i2.262

Herliandry, L. D., \& Suban, M. E. (2020). Pembelajaran Pada Masa Pandemi Covid-19 Luh. Jurnal Teknologi Pendidikan, 22(1), 65-70.

Ismail, M. I. (2010). Kinerja Dan Kompetensi Guru Dalam Pembelajaran. Lentera Pendidikan: Jurnal Ilmu Tarbiyah Dan Keguruan, 13(1), 44-63. https://doi.org/10.24252/lp.2010v13n1a4

Jamilah, Mahutma Gandhi, I. K. S. (2015). Muallimuna: Kompetensi Guru SD di Banjarmasin dalam Merancang Perangkat Penilain Tematik. Muallimuna: Jurnal Madrasah Ibtidaiyah, 3(2), 116-127.

Jamilah, Mahutma Gandhi, I. K. S. (2020). Kompetensi Guru SD Banjarmasin Dalam Merancang Perangkat Penilaian Tematik. Muallimuna: Jurnal Madrasah Ibtidaiyah, 5(2), 13-20.

Kahfi, A. (2020). Tantangan Dan Harapan Pembelajaran Jarak Jauh Di Masa Pandemi Covid 19. Dirasah, 03(2), 137-154. https://stai-binamadani.ejournal.id/jurdir

Kusmarni, Y. (2015). STUDI KASUS ( John W. Creswell ) Oleh Yani Kusmarni. Artikel Studi Kasus John W. Creswell, 1-12.

LONDA, C. G. S. A. L. V. Y. (2020). KINERJA GURU SEKOLAH DASAR DI MASA PANDEMI COVID-19. Journal of Chemical Information and Modeling, 53(9), 1689-1699.

Lubis, R. R., \& Nasution, M. H. (2017). Implementasi Pendidikan Karakter di Madrasah Ibtidaiyah. JIP: Jurnal Ilmiah PGMI, 3(1), 15-32. https://doi.org/10.19109/jip.v3i1.1375

Mujahidin, A. (2019). Metode Penelitian Kualitatif di Bidang Pendidikan. In Buku Metode Penelitian Kualitatif Bidang Pendidikan (Vol. 53, Issue 9). http://repository.iainponorogo.ac.id/484/1/METODE

PENELITIAN KUALITATIF DI BIDANG PENDIDIKAN.pdf

Nengsih, H. D. (2017). Analisis Kompetensi Pedagogik Guru Dalam Pengelolaan Proses Di Sd Negeri 10 Mandonga. Wakapendik, 2(7), 1-14.

Novitasari, D., \& Asbari, M. (2020). Peran Kesiapan untuk Berubah terhadap Kinerja Guru di Masa Pandemi Covid-19. Journal of Industrial Engineering \& Management Research (JIEMAR), 1(2), 219-237. https://jiemar.org/index.php/jiemar/article/view/63

Pristiyono, Ikhlash, M., Rafika, M., \& Hasibuan, D. K. (2020). Implementasi Work from Home terhadap Motivasi dan Kinerja Dosen di Indonesia. Jurnal Akuntansi, Ekonomi Dan Manajemen Bisnis, 8(2), 263-269. 
Purwanto, A. (2020). Studi eksplorasi Dampak WFH Terhadap Kinerja Guru. Journal of Education, Psychology and Counseling, 2(1), 92-100.

Rachmawati, I. N. (2007). Pengumpulan Data Dalam Penelitian Kualitatif: WaRachmawati, I. N. (2007). Pengumpulan Data Dalam Penelitian Kualitatif: Wawancara. Jurnal Keperawatan Indonesia, 11(1), 35-40. https://doi.org/10.7454/jki.v11i1.184wancara. Jurnal Keperawatan Indonesia, 11(1), 35-40.

Ranti, G. (2018). Pengabdian Cakrawala Nusantara Untuk Membangkitkan Daya Saing Anak Pesisir Melalui Pendidikan. Journal of Community Development, 2(1), 21-27. https://doi.org/10.30874/comdev.2017.43

Seknun, M. Y. (2012). Kedudukan Guru Sebagai Pendidik. Lentera Pendidikan: Jurnal Ilmu Tarbiyah Dan Keguruan, 15(1), 120-131. https://doi.org/10.24252/lp.2012v15n1a10

Sodik, M., Sahal, Y. F. D., \& Herlina, N. H. (2019). Pengaruh Kinerja Guru dalam Pelaksanaan Pembelajaran terhadap Prestasi Belajar Siswa pada Mata Pelajaran Alquran Hadis. Jurnal Penelitian Pendidikan Islam, 7(1), 97. https://doi.org/10.36667/jppi.v7i1.359

Suasthi, I. G. A., Bagus, I., \& Eka, P. (2020). Membangun Karakter " Genius " Anak Tetap Belajar Dari Rumah Selama Pandemi Covid - 19 Pada Sekolah Suta Dharma Ubud Gianyar. Cetta:Jurnal Ilmu Pendidikan, 3(3), 431-451.

Suwartono. (n.d.). Akrab Dengan Penelitian. Buku Penelitian, 2007.

Tri, S. R. C. (2020). Pengaruh Work From Home (WFH) Terhadap Kinerja Guru SD Negeri Dengkek 01 Pati Selama Masa Pandemi Covid-19. EduPsyCouns: Journal of Education, Psychology and Counseling, 2(1), 424-437. https://ummaspul.e-journal.id/Edupsycouns/article/view/500

Wahidmurni. (2017). PEMAPARAN METODE PENELITIAN KUALITATIF. Tarbiyah Malik Ibrahim, 4, 9-15. 